\title{
PARTISIPASI PLS MELALUI KADER POS PELAYANAN (POSYANDU) "SERUNI" DALAM PENYULUHAN PEMBANGUNAN KESEHATAN DI MASYARAKAT RW 10 KELURAHAN KAHURIPAN KECAMATAN TAWANG KOTA TASIKMALYA
}

\author{
Syafuddin'1, Adang Danial'2 ${ }^{2}$ Lulu Yuliani $^{3}$ \\ 1,2,3 Prodi Pendidikan Masyarakat, Universitas Siliwangi, Tasikmalaya, Indonesia \\ ${ }^{1}$ syaefuddin@unsil.ac.id
}

\begin{abstract}
ABSTRAK
Penelitian ini bertujuan untuk mengetahui Partisipasi PLS melalui Kader Pos Pelayanan Terpadu (Posyandu) "Seruni" Dalam Penyuluhan Pembangunan Kesehatan Masyarakat Di Rw 10 Kelurahan Kahuripan Kecamatan Tawang Kota Tasikmalaya. Target yang hendak dicapai Mendeskripsikan Partisipasi PLS melalui Kader Pos Pelayanan Terpadu (posyandu)" Seruni "Dalam Penyuluhan Pembangunan Kesehatan Masyarakat Di Rw 10 Kelurahan Kahuripan Kecamatan Tawang Kota Tasikmalaya. Menghasilkan rekomendasi keilmuan Pendidikan Luar Sekolah, mempublikasikan hasil penelitian pada prosiding, jurnal nasional maupun Internasioanal. Penelitian ini menggunakan pendekatan kualitatif untuk mendapatkan data yang mendalam, suatu data yang mengandung makna. Peneliti mengadakan pengamatan dan mencari data deskriptif berupa kata-kata tertulis atau lisan dari responden yang diamati. Peneliti secara terus menerus melaksanakan wawancara dengan informan secara mendalam untuk mengumpulkan data dari kader Posyandu. Teknik yang di gunakan, Teknik Triangulasi Data yaitu Wawancara, Observasi, dan Dokumentasi. Hasil penelitian menunjukkan bahwa ada bentuk partisipasi PLS melalui kader Posyandu, seperti tenaga, uang dan ikut dalam pelaksanaan program. Hal tersebut dipengaruhi oleh faktor internal dan eksternal, seperti pengetahuan, usia, pekerjaan, keluarga dan lokasi posyandu, serta upaya yang dilakukan kader untuk meningkatkan kesehatan balita dengan cara memberikan makanan tambahan, pemberian vitamin secara rutin setiap 6 bulan sekali, memberikan arahan dan penyuluhan mengenai kesehatan dan makanan bergizi untuk balita.
\end{abstract}

Kata Kunci: Partisipasi PLS, Penyuluhan Pembangunan Kesehatan Masyarakat

\section{PENDAHULUAN}

Pos Pelayanan Terpadu atau Posyandu merupakan bagian dari pembangunan kesehatan yang diprogramkan oleh pemerintah dimana sasarannya adalah pembangunan kesehatan untuk mencapai keluarga kecil, bahagia dan sejahtera yang dilaksanakan oleh keluarga, bersama masyarakat dengan bimbingan dari petugas kesehatan setempat.

Kontribusi posyandu dalam meningkatkan kesehatan bayi dan anak balita sangat besar, namun sampai saat ini kualitas pelayanan posyandu masih perlu ditingkatkan. Keberadaan kader dan sarana yang ada merupakan modal dalam keberlanjutan posyandu. Oleh karena itu keberadaan posyandu harus terus ditingkatkan sehingga diklasifikasikan menjadi 4 jenis yaitu posyandu pratama, madya, purnama, dan mandiri.

Pembangunan kesehatan dalam tahun periode 2017-2019 difokuskan pada empat program prioritas yaitu penurunan angka kematian ibu dan bayi, penurunan prevalensi 
balita pendek (stunting), pengendalian penyakit menular dan pengendalian penyakit tidak menular.

Revitalisasi Posyandu merupakan upaya pemberdayaan Posyandu untuk mengurangi dampak dari krisis ekonomi terhadap penurunan status gizi dan kesehatan ibu dan anak. Kegiatan ini juga bertujuan untuk meningkatkan pemberdayaan masyarakat dalam menunjang upaya mempertahankan dan meningkatkan status gizi serta kesehatan ibu dan anak melalui kemampuan kader, manajemen, dan fungsi Posyandu.

Kader Posyandu, menurut Depkes RI (2003) adalah anggota masyarakat yang dipilih dari dan oleh masyarakat, mau dan mampu bekerja bersama dalam berbagai kegiatan kemasyarakatan secara sukarela.

Pendidikan Luar Sekolah memiliki peran yang sangat penting dalam mempengaruhi perubahan suatu masyarakat. Partisipasi Pendidikan Luar Sekolah dapat di wujudkan dalam membangun gerakan pemberdayaan masyarakat melalui Kader Posyandu dalam penyuluhan pembangunan kesehatan masyarakat.

Partisipasi PLS melalui kader Posyandu merupakan salah satu program pemberdayaan masyarakat dalam bidang kesehatan, kader Posyandu merupakan bagian dari tenaga PLS yang menjadi tenaga utama pelaksana Posyandu, yang menentukan kualitas pelayanan yang dilaksanakan.

Berdasarkan realita dilapangan, rendahnya partisipasi PLS melalui kader Posyandu berdampak pada rendahnya kegiatan pemantauan tingkat status gizi anak, ibu hamil dan menyusui, yang pada akhirnya tidak dapat memenuhi kebutuhan dataperkembangan status gizi anak balita di Posyandu. Masalah lain yang ditemukan adalah : 1) rendahnya cakupan hasil penimbangan balita di Posyandu, 2) belum tersosialisasinya program-program upaya perbaikan gizi ke masyarakat, serta 3) masih rendahnya pengetahuan gizi yang dimiliki oleh masyarakat di desa. Pada umumnya, halhal tersebut diatas menjadi beban kader, yang sampai saat ini belum dapat diselesaikan dan diatasi.

Penelitian ini bertujuan untuk mengetahui Partisipasi PLS melalui Kader Pos Pelayanan Terpadu (Posyandu) "Seruni" Dalam Penyuluhan Pembangunan Kesehatan Masyarakat Di Rw 10 Kelurahan Kahuripan Kecamatan Tawang Kota Tasikmalaya.

\section{METODE PENELITIAN}

Penelitian ini menggunakan pendekatan kualitatif untuk mendapatkan data yang mendalam. Pengambilan sumber data di dalam penelitian ini menggunakan teknik purposive sampling. Menurut Sugiyono (2010, hlm 300) mengemukakan bahwa teknik purposive sampling adalah teknik pengambilan sumber data atau responden dengan pertimbangan tertentu.

Partisipan merupakan sumber utama yang memiliki kedudukan penting dalam suatu penelitian, karena didalam subyek penelitian inilah terdapat variabel-variabel yang menjadi kajian untuk diteliti. Partisipan atau informan adalah kader Posyandu yang melaksanakan penyuluhan pembangunan kesehatan dimasyarakat Rw 10 Kelurahan Kahuripan Kecamatan Tawang kota Tasikmalaya.

Subyek penelitian yang utama dari studi penelitian ini adalah 4 orang kader Posyandu, yang memiliki peran langsung dalam melakukan pemberdayaan kesehatan ibu dan 
anak. Disamping itu ada 1 orang bidan yang juga berperan untuk membantu kegiatan di Posyandu.

Data yang dibutuhkan dalam penelitian ini menggunakan teknik pengumpulan yang disesuaikan dengan kebutuhan, adapun teknik yang digunakan dalam penelitian ini yaitu; pengamatan/observasi, wawancara, dan studi dokumentasi.

\section{HASIL DAN PEMBAHASAN}

Posyandu Seruni terbentuk sejak tahun 1987 dengan jumlah kader 4 orang. Posyandu Seruni sangat berperan aktif dalam membantu memberikan pengetahuan tentang kesehatan kepada masyarakat sekitar. Secara perlahan masyarakat memahami pentingnya PHBS, makanan bergizi dan lain sebagainya. Kader posyandu memberikan sosialisasi kepada masyarakat tentang pentingnya pola hidup sehat serta memberikan pendampingan kepada masyarakat.

Kader adalah warga masyarakat yang dipilih dan ditinjau oleh masyarakat dan dapat bekerja secara sukarela. Anggota masyarakat yang bersedia, mampu dan memiliki waktu untuk menyelenggarakan kegiatan posyandu (Kementrian Kesehatan RI, 2011;19).

Notoatmojo (2010,hlm. 274) menjelaskan bahwa partisipasi masyarakat adalah keterlibatan masyarakat yang diwujudkan dalam bentuk menjalin kemitraan diantara masyarakat dan pemeriintah dalam perencanaan, implementasi, dan berbagai aktivitas program kesehatan, mulai dari pendidikan kesehatan, pengembangan program kemandirian dalam kesehatan, sampai dengan mengontrol perilaku masyarakat dalam menghadapi teknologi dan infrastruktur kesehatan.

Bahwa partisipasi kader dalam penyuluhan kesehatan adalah bentuk partisipasi yang dilakukan oleh masyarakat dalam hal ini khususnya para ibu, baik ibu yang menjadi kader maupun ibu balita yaitu partisipasi dalam bentuk tenaga, uang/harta benda dan ikut dalam pelaksanaan program. Upaya yang dilakukan kader untuk meningkatkan kesehatan balita ialah dengan memberikan arahan kepada ibu balita untuk memberikan makanan yang bergizi, penyuluhan tentang kesehatan, pemantauan dalam timbangan, imunisasi serta pemberian vitamin A dan B kepada balita dan adanya program baru yaitu berupa pemberian hadiah atau apresiasi kepada balita.

Partisipasi kader posyandu yaitu melakukan penyuluhan kesehatan kader dengan menyebarluaskan informasi hari buka posyandu sebelum posyandu dilaksanakan, dengan menggunakan fasilitas umum yaitu dengan menggunakan pengeras suara di masjid setempat. Kader berpartisipasi dalam perencanaan, persiapan, pelaksanaan dan evaluasi kegiatan posyandu.

Partisipasi PLS dalam kegiatan posyandu bersama kader dalam penyuluhan pembangunan kesehatan di Rw 1o Kelurahan Kahuripan Kecamatan Tawang, yaitu dengan pembagian tugas kader posyandu sesuai dengan langkah kegiatan dalam posyandu yaitu pendaftaran, penimbangan, pencatatan, penyuluhan, pelayanan kesehatan.

Partisipasi PLS melalui kader Posyandu maka dapat ditarik teori substansial adalah pendidikan kesehatan yang diberikan pada ibu balita yaitu kegiatan penyuluhan yang diberikan oleh bidan dan kader dengan berbagai materi seperti cara pengasuhan yang baik untuk anak, pemberian makanan sehat, dan KB. Sedangkan pendidikan untuk 
kader posyandu berupa pelatihan dasar selama 2 minggu di puskesmas, kegiatan pelatihan dilakukan oleh bidan, ahli gizi, dan petugas kesehatan yang bbertugas. Selanjutnya kader mendapat penyegaran setiap satu bulan sekali pada rapat bulanan PKK.

\section{KESIMPULAN}

Hasil penelitian menunjukkan bahwa ada tiga bentuk partisipasi yang dilakukan oleh kader, seperti tenaga, uang dan ikut dalam pelaksanaan program. Hal tersebut dipengaruhi oleh faktor internal dan eksternal, seperti pengetahuan, usia, pekerjaan, keluarga dan lokasi posyandu, serta upaya yang dilakukan kader untuk meningkatkan kesehatan balita dengan cara memberikan makanan tambahan (PMT), pemberian vitamin secara rutin setiap 6 bulan sekali, memberikan arahan dan penyuluhan mengenai kesehatan dan makanan bergizi untuk balita.

Bentuk partisipasi yang dilakukan oleh masyarakat dalam hal ini khususnya para ibu, baik ibu yang menjadi kader maupun ibu balita yaitu partisipasi dalam bentuk tenaga, uang/harta benda dan ikut dalam pelaksanaan program. Upaya yang dilakukan kader untuk meningkatkan kesehatan balita ialah dengan memberikan arahan kepada ibu balita, KIA, untuk memberikan makanan yang bergizi, penyuluhan tentang kesehatan, pemantauan dalam timbangan, imunisasi, KB, serta pemberian vitamin A dan B kepada balita dan adanya program baru yaitu berupa pemberian hadiah atau apresiasi kepada balita.

\section{DAFTAR PUSTAKA}

Arikunto, S. (1996). Dasar- dasar Evaluasi Pendidikan, Jakarta: Rineka Cipta.

Creswell, W. John. (2014). Research Design: Pendekatan Kualitatif, Kuantitatif, dan Mixed. Yogyakarta: Pustaka Pelajar.

DEPDIKNAS. (2003). Undang-Undang Republik Indonesia Nomer 20 Tahun 2003 Tentang Sistem Pendidikan Nasional.

DepKes RI. (1999). Pembangunan Kesehatan Menuju Indonesia Sehat. 2012: : Visi Baru, Misi, Kebijakan, dan Strategi Pembangunan Kesehatan. Jakarta

Depkes RI. (2004). Profil Kesehatan Indonesia. Jakarta: Departemen Kesehatan Republik Indonesia

DepKes RI.( 2006). Pedoman Umum Pengelolaan Posyandu. Jakarta: Departemen Kesehatan RI.

Effendy, Nasrul. 1998. Dasar-Dasar Keperawatan Kesehatan Masyarakat. Jakarta: EGC.

Emzir. (2012). Metode Penelitian Kualitatif: Analisis Data. Jakarta: Rajawali Pers.

Hapsara,.(1968). orientasi kesehatan kepada masyarakat. Jakarta: pustaka pelajar.

Hartono, B.( 2001). Penataan Sistem Kesehatan Daerah. Departemen Kesehatan RI, Jakarta.

Ismawati, C.( 2010). Posyandu dan Desa Siaga panduan untuk Bidan dan Kader. Nuha Medika. Jakarta. 
Kamil, M (2009). Pendidikan Non Formal : Pengembangan Melalui PKBM Di Indonesia. Bandung: Alfabeta.

Kementrian Pendidikan RI. (2011). Manfaat Deteksi Dini Tumbuh Kembang Anak.

Kementrian Kesehatan RI.2011. Pedoman Umum Posyandu. . (2011). Buku Panduan Kader Posyandu Menuju Keluarga Sadar Gizi.

Moloeng, J. (2011). Metodelogi Penelitian Kualitatif. Bandung: Rosda.

Miles M.B \& Huberman , A.M. (1992). Analisis Data Kualitatif. Jakarta: Penerbit Universitas Indonesia. Terjemahan, Rohidi, Tjeptjep Rohendi. Judul Asli: Qualitative Data Analysis.

Muninjaya, A, G. (2004). Manajemen Kesehatan.Jakarta: Kementerian Pendidikan Nasional RI.

Nasution, (2003). Metode Penelitian Naturalistik Kualitatif. Bandung : Tarsito.

Notoatmojo, Soekidjo. (2010). Promosi Kesehatan Teori dan Aplikasi. Jakarta: RekaCipta. . (2003). Ilmu Kesehatan Masyarakat. Jakarta: Reka Cipta.

Petunjuk Teknis Pedoman Umum Pengelolaan Posyandu. Jakarta : Kementerian Kesehatan RI. 2011.

Sudjana, H.D. (2004). Pendidikan Non Formal, Bandung: Falah Production.

Sugiyono. (2010). Metode Penelitian Pendidikan: Pendekatan Kuantitatif, Kualitatif, dan R\&D. Bandung: Alfabeta.

Syodih. S, (2007). Metode Penelitian Pendidikan. Kerja Sama Program Pascasarjana UPI Bandung: Remaja Rosdakarya.

Widiastuti, I Gusti Agung Ayu dan Kristiani. (2006) Pemanfaatan Pelayanan Posyandu di Kota Denpasar. Universitas Gadjah Mada: Yogyakarta. 